(C) by Oldenbourg Wissenschaftsverlag, München

\title{
Refinement of the crystal structure of $\mathrm{N}$-4-nitrophenylphosphoramidic acid dimethyl ester, $\left(\mathrm{CH}_{3} \mathrm{O}\right)_{2} \mathrm{PONHC}_{6} \mathrm{H}_{4} \mathrm{NO}_{2}$, at $120 \mathrm{~K}$
}

\author{
K. Gholivand*, Z. Shariatinia and M. Pourayoubi \\ Tarbiat Modarres University, School of Science, Department of Chemistry, P.O. Box 14115-175, Tehran, I. R. Iran
}

Received November 8, 2004, accepted and available on-line January 5, 2005; CCDC no. 1267/1426

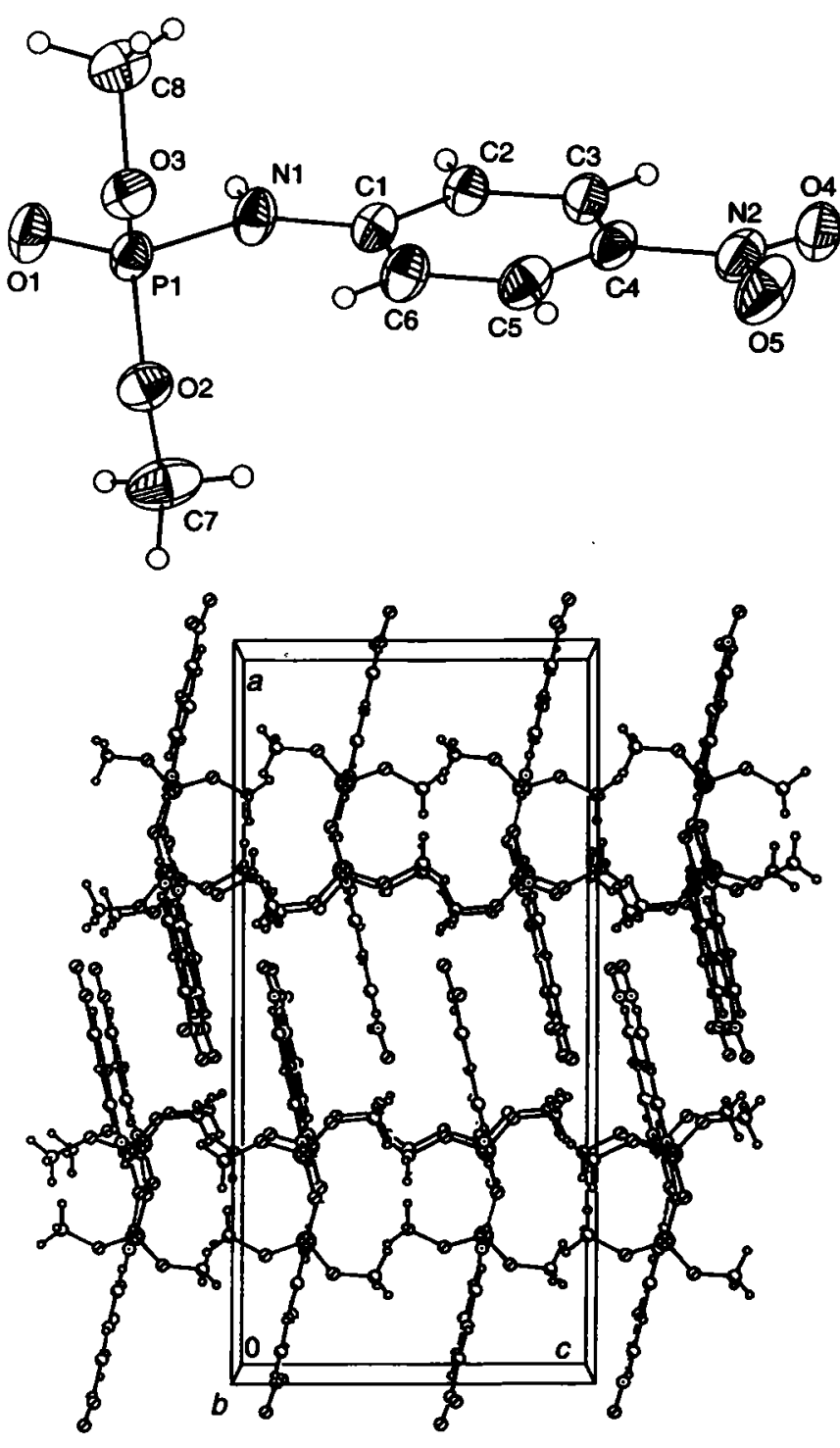

Abstract

$\mathrm{C}_{8} \mathrm{H}_{11} \mathrm{~N}_{2} \mathrm{O}_{5} \mathrm{P}$, orthorhombic, Pbcn (no. 60), $a=24.714(5) \AA$, $b=7.330(1) \AA, c=11.980(2) \AA, V=2170.3 \AA^{3}, Z=8$, $R_{\mathrm{gt}}(F)=0.054, w R_{\mathrm{ref}}\left(F^{2}\right)=0.128, T=120 \mathrm{~K}$.

\section{Source of material}

The title compound was synthesized according to a well-established method [1,2]. Crystals were obtained from a mixture of $\boldsymbol{n}$ heptane and methanol after slow evaporation at room temperature.
Elemental analysis: found - C, 38.95\%; $\mathrm{H}, 4.46 \% ; \mathrm{N}, 11.41 \%$; calc. for $\mathrm{C}_{8} \mathrm{H}_{11} \mathrm{~N}_{2} \mathrm{O}_{5} \mathrm{P}-\mathrm{C}, 39.03 \% ; \mathrm{H}, 4.50 \% ; \mathrm{N}, 11.38 \%$.

\section{Discussion}

Phosphoramidic acid esters have attracted attention due to their synthetic and biological applications $[3,4]$. So far, the structures have been determined only for a few molecules of this series [5]. Here, we report the crystal structure of $N$-4-nitrophenyl phosphoramidic acid dimethyl ester at $120 \mathrm{~K}$ which confirms the result at $283 \mathrm{~K}-303 \mathrm{~K}$ [1]. Methoxy groups in this structure (figure, top) have syn orientation to each other. Molecule is obtained as polymeric chain produced by $-\mathrm{P}=\mathrm{O} \cdots \mathrm{H}-\mathrm{N}-$ hydrogen bond (figure, bottom). Furthermore, there are $\mathrm{C} 2-\mathrm{H} 2 \mathrm{~A} \cdots \mathrm{O} 1^{\prime}$ and $\mathrm{C} 7-\mathrm{H} 7 \mathrm{~A} \cdots \mathrm{O} 4^{\prime}$ weak hydrogen bonds in the crystal with $d\left(\mathrm{C} 2_{2} \cdots \mathrm{O1}^{\prime}\right)=3.352 \AA$, $\angle C 2-H 2 A \cdots O 1^{\prime}=135.9^{\circ}$ and $d\left(C 7 \cdots .04^{\prime}\right)=3.302 \AA, \angle C 7-H 7 A \cdot .04^{\prime}=$ $133.6^{\circ}$, respectively. Another feature of the structure is the electrostatic interaction between $\mathrm{N} 2-04$ in one molecule with $04^{\prime}-\mathrm{N} 2{ }^{\prime}$ in neighboring molecule (two equivalent N2...04 interactions with distances that are equal to $2.966 \AA$ ).

The $\mathrm{P} 1-\mathrm{O} 2$ and $\mathrm{P} 1-\mathrm{O} 3$ bond lengths are 1.563(2) $\AA$ and $1.571(2) \AA$, respectively, which are smaller than the $\mathrm{P}-\mathrm{O}$ single bond length (1.64 $\AA$ [6]). The bond angles C7-O2-P1 and C8-03-P1 are $120.1(1)^{\circ}$ and $121.0(1)^{\circ}$, respectively, corresponding to $s p^{2}$ hybridization bond angles. Also, the $\mathrm{P}-\mathrm{N}$ bond length $(1.639(2) \AA)$ is shorter than the $\mathrm{P}-\mathrm{N}$ single bond length $(1.77 \AA[6])$ and the nitrogen atom is nearly planar. The deviation from planarity can be supported by the torsion angle H1N-P1$\mathrm{C} 1-\mathrm{N} 1$ being about $0.4^{\circ}$. The sum of the angles around nitrogen atom is $360.0^{\circ}$. The angles $\mathrm{C} 1-\mathrm{N} 1-\mathrm{H} 1 \mathrm{~N}$ and $\mathrm{P} 1-\mathrm{N} 1-\mathrm{Cl}$ are $122.8^{\circ}$ and $128.9^{\circ}$, respectively and the angle $\mathrm{P} 1-\mathrm{N} 1-\mathrm{H} 1 \mathrm{~N}$ is smaller $\left(108.4^{\circ}\right)$. The phosphorus atom has a distorted tetrahedral coordination. The surrounding angles of $P 1$ are in the range of $96.5^{\circ}-116.9^{\circ}$. The minimum and maximum values of angles are observed for angles $\mathrm{O} 2-\mathrm{P} 1-\mathrm{O} 3$ and $\mathrm{O} 1-\mathrm{P} 1-\mathrm{O} 2$, respectively.

Table 1. Data collection and handling.

* Correspondence author (e-mail: gholi_kh@modares.ac.ir) 
Table 2. Atomic coordinates and displacement parameters (in $\AA^{2}$ ).

\begin{tabular}{llllll}
\hline Atom & Site & $x$ & $y$ & $z$ & $U_{\text {iso }}$ \\
\hline H(1N) & $8 d$ & 0.2972 & -0.0632 & 0.2031 & 0.056 \\
H(2A) & $8 d$ & 0.3466 & -0.3442 & 0.1856 & 0.034 \\
H(3A) & $8 d$ & 0.4267 & -0.4956 & 0.1490 & 0.039 \\
H(5A) & $8 d$ & 0.5022 & -0.0142 & 0.1075 & 0.042 \\
H(6A) & $8 d$ & 0.4215 & 0.1385 & 0.1421 & 0.040 \\
H(7A) & $8 d$ & 0.3830 & 0.3398 & 0.4279 & 0.070 \\
\hline
\end{tabular}

Table 2. Continued.

\begin{tabular}{llllll}
\hline Atom & Site & $x$ & $y$ & $z$ & \multicolumn{1}{c}{$U_{\text {iso }}$} \\
\hline H(7B) & $8 d$ & 0.3741 & 0.1352 & 0.3944 & 0.070 \\
H(7C) & $8 d$ & 0.3243 & 0.2584 & 0.4247 & 0.070 \\
H(8A) & $8 d$ & 0.3253 & 0.3107 & -0.0787 & 0.069 \\
H(8B) & $8 d$ & 0.2686 & 0.3250 & -0.0205 & 0.069 \\
H(8C) & $8 d$ & 0.2991 & 0.1375 & -0.0243 & 0.069 \\
& & & & & \\
\hline
\end{tabular}

Table 3. Atomic coordinates and displacement parameters (in $\AA^{2}$ ).

\begin{tabular}{|c|c|c|c|c|c|c|c|c|c|c|}
\hline Atom & Site & $x$ & $y$ & $z$ & $U_{11}$ & $U_{22}$ & $U_{33}$ & $U_{12}$ & $U_{13}$ & $U_{23}$ \\
\hline$P(1)$ & $8 d$ & $0.31166(2)$ & $0.21461(7)$ & $0.19758(5)$ & $0.0215(2)$ & $0.0241(2)$ & $0.0372(3)$ & $-0.0000(2)$ & $-0.0024(2)$ & $0.0012(2)$ \\
\hline$O(1)$ & $8 d$ & $0.25467(5)$ & $0.2336(2)$ & $0.2297(1)$ & $0.0211(6)$ & $0.0307(7)$ & $0.0542(9)$ & $0.0038(5)$ & $0.0005(6)$ & $0.0007(7)$ \\
\hline$O(2)$ & $8 d$ & $0.35437(6)$ & $0.3094(2)$ & $0.2744(1)$ & $0.0289(7)$ & $0.0341(7)$ & $0.0350(8)$ & $-0.0072(6)$ & $-0.0034(6)$ & $0.0021(6)$ \\
\hline$O(3)$ & $8 d$ & $0.32954(6)$ & $0.3097(2)$ & $0.0860(1)$ & $0.0351(7)$ & $0.0313(7)$ & $0.0349(8)$ & $-0.0033(6)$ & $-0.0046(6)$ & $0.0032(6)$ \\
\hline$O(4)$ & $8 d$ & $0.52296(7)$ & $-0.5309(3)$ & $0.1162(1)$ & $0.0455(9)$ & $0.060(1)$ & $0.0397(9)$ & $0.0275(8)$ & $-0.0042(7)$ & $-0.0057(8)$ \\
\hline$O(5)$ & $8 d$ & $0.56206(6)$ & $-0.2734(3)$ & $0.0769(2)$ & $0.0271(8)$ & $0.090(1)$ & $0.043(1)$ & $0.0152(8)$ & $0.0096(7)$ & $0.0139(9)$ \\
\hline$N(2)$ & $8 d$ & $0.52200(7)$ & $-0.3637(3)$ & $0.1041(2)$ & $0.0311(9)$ & $0.068(1)$ & $0.0263(9)$ & $0.0180(9)$ & $-0.0004(7)$ & $0.0002(9)$ \\
\hline$C(1)$ & $8 d$ & $0.37564(7)$ & $-0.0875(3)$ & $0.1677(2)$ & $0.0225(8)$ & $0.0311(9)$ & $0.031(1)$ & $0.0020(7)$ & $-0.0008(7)$ & $0.0026(8)$ \\
\hline$C(2)$ & $8 d$ & $0.37775(7)$ & $-0.2779(3)$ & $0.1697(2)$ & $0.0233(8)$ & $0.0294(9)$ & $0.032(1)$ & $0.0017(7)$ & $0.0005(7)$ & $0.0015(8)$ \\
\hline$C(3)$ & $8 d$ & $0.42544(8)$ & $-0.3688(3)$ & $0.1482(2)$ & $0.0297(9)$ & $0.037(1)$ & $0.031(1)$ & $0.0085(8)$ & $-0.0013(8)$ & $-0.0001(8)$ \\
\hline$C(4)$ & $8 d$ & $0.47160(8)$ & $-0.2667(3)$ & $0.1253(2)$ & $0.0250(9)$ & $0.052(1)$ & $0.0224(9)$ & $0.0113(8)$ & $0.0012(7)$ & $0.0017(8)$ \\
\hline$C(5)$ & $8 d$ & $0.47079(8)$ & $-0.0794(3)$ & $0.1230(2)$ & $0.0230(9)$ & $0.048(1)$ & $0.033(1)$ & $-0.0001(8)$ & $0.0027(8)$ & $0.0062(9)$ \\
\hline$C(6)$ & $8 d$ & $0.42256(7)$ & $0.0117(3)$ & $0.1439(2)$ & $0.0240(8)$ & $0.034(1)$ & $0.041(1)$ & $0.0007(8)$ & $0.0027(8)$ & $0.0071(9)$ \\
\hline
\end{tabular}

Acknowledgments. Support of this investigation by Tarbiat Modarres University is gratefully acknowledged. We thank the Institute of Organoelement Compounds of the Russian Academy of Science for determining the crystal structure.

\section{References}

1. Du Plessis, M.-P.; Modro, T.-A.; Nassimbeni, L.-R.: Hydrogen bonding in phosphoramides: Structures of dimethyl $N$-phenylphosphoramidate and dimethyl $N$-(p-nitrophenyl)phosphoramidate. Acta Crystallogr. B38 (1982) 1504-1507.

2. Gholivand, K.; Shariatinia, Z.; Pourayoubi, M.: Crystal Structure of and $a b$ initio Calculations on $\left[\left(\mathrm{C}_{6} \mathrm{H}_{5}\right)\left(\mathrm{CH}_{3}\right) \mathrm{CH}-\mathrm{NH}\right] \mathrm{P}(\mathrm{O})\left(\mathrm{p}-\mathrm{OC}_{6} \mathrm{H}_{4} \mathrm{CH}_{3}\right)_{2}$, Syntheses and Spectroscopic Characterization of $N$-Benzyl Phosphoramidic Acid (4-methylphenyl)ester Derivatives. Z. Naturforsch. 60b (2005) 67-74.
3. Pang, Y.-P.; Kollmeyer, T.-M.; Hong, F.; Lee, J.-C.; Hammond, P.-I.; Haugabouk, S.-P.; Brimijoin, S.: Rational design of alkylene-linked bispyridiniumaldoximes improved acetylcholinesterase reactivators. Chem. Biol. 10 (2003) 491-502.

4. Baldwin, A.; Huang, Z.; Jounaidi, Y.; Waxman, D.-J.: Identification of novel enzyme-prodrug combinations for use in cytochrome $P_{450}$-based gene therapy for cancer. Arch. Biochem. Biophys. 409 (2003) 197-206.

5. Gholivand, K.; Tadjarodi, A.; Taeb, A.; Garivani, G.; Ng, S.-W.: Bis(4nitrophenyl)- $N, N$-dimethylphosphoramidate. Acta Crystallogr. E57 (2001) 472-473.

6. Corbridge, D. E. C.: Phosphorus, an outline of it's Chemistry, Biochemistry and Technology. Fifth Edition. Elsevier, The Netherlands 1995.

7. Sheldrick, G. M.: SHELXTL. Structure Determination Software Suite. V. 5.10. Bruker AXS, Madison, Wisconsin, USA 1998. 